\title{
Analisis Arah Global Health Diplomacy Indonesia dalam COVID-19: Kooperatif atau Kompetitif?
}

\author{
Dovana Hasiana \\ Program Studi Ilmu Hubungan Internasional, UPN Veteran Jakarta \\ dovanahasiana@upnvj.ac.id \\ Richo Sunjaya \\ Program Studi Ilmu Hubungan Internasional, UPN Veteran Jakarta \\ richosunjaya@upnvj.ac.id \\ Salsabilla Putri B \\ Program Studi Ilmu Hubungan Internasional, UPN Veteran Jakarta \\ salsabillaputrib@upnvj.ac.id \\ Clariza Farell \\ Program Studi Ilmu Hubungan Internasional, UPN Veteran Jakarta \\ clarizafarell@upnvj.ac.id
}

\begin{abstract}
Background: Global Health Diplomacy can be used as an instrument that can be applied by every country. This can be seen through the Me First Policy at the beginning of the Pandemic. Objective: This paper aims to analyze the direction of Indonesia's policy through Global Health Diplomacy during the COVID-19 period and to analyze whether the policy is cooperative or competitive. The results found that Indonesia's role in the implementation of global health diplomacy was to become the leader of the global health program, assist the state and ensure the public good to create health resilience in the community. In addition, Indonesia has also created a cooperative pattern in global health diplomacy to ensure that bilateral cooperation runs smoothly through vaccine assistance, availability of media tools, assistance for health workers and other forms. This pattern of cooperation is a model of alturism that puts the public interest above personal or group interests.
\end{abstract}

Keywords: COVID-19, Global Health Diplomacy, Indonesia, Cooperative, Competitive 


\begin{abstract}
Abstrak
Latar Belakang: Global Health Diplomacy dapat digunakan sebagai salah satu instrumen yang dapat diterapkan oleh setiap negara.. Hal tersebut dapat dilihat melalui kebijakan Me First Policy pada awal masa Pandemi. Tujuan: Paper ini bertujuan untuk menganalisis arah kebijakan Indonesia melalui Global Health Diplomacy pada masa COVID - 19 dan untuk menganalisis apakah kebijakan tersebut bersifat kooperatif atau kompetitif. Hasil yang ditemukan bahwa peran Indonesia dalam implementasi global health diplomacy dengan menjadi pemimpin program global Kesehatan, pendampingan terhadap negara dan memastikan public good untuk menciptakan ketahanan Kesehatan pada masyarakat. Selain itu, Indonesia juga menciptakan pola kooperatif dalam global health diplomasi untuk memastikan kerjasama bilateral berjalan lancer baik melalui bantuan vaksin, ketersediaan lat media, bantuan tenaga Kesehatan dan bentuk lainya. Pola kerjasama seperti ini merupakan model alturisme yang mememntingkan kepentingan umum dibandingkan kepentingan pribadi atau glongan.
\end{abstract}

Kata kunci: COVID - 19, Diplomasi Kesehatan Global, Indonesia, Kooperatif, Kompetitif

\section{Pendahuluan}

Seperti yang telah menjadi diskusi oleh para aktor dalam hubungan internasional, COVID - 19 digambarkan sebagai peristiwa yang unprecedented. Terminologi tersebut mengacu pada sebuah peristiwa yang belum pernah terjadi sebelumnya. Walaupun COVID - 19 bukan merupakan isu kesehatan pertama yang memberikan pengaruh pada dunia internasional, namun kompleksitas dari dampak yang diberikan oleh pandemi tersebut memberikan pengaruh yang signifikan dan mampu mengubah tatanan internasional.

Dampak yang diberikan oleh peristiwa tersebut tidak hanya terjadi dalam aspek kesehatan, melainkan memberikan efek spillover ke dalam berbagai aspek lainnya, seperti ekonomi dan sosial. Lebih lanjut, World Health Organization (WHO) telah mengidentifikasi dampak yang diberikan pandemi terhadap isu selain kesehatan, salah satunya adalah ketahanan pangan. Hal tersebut tertuang dalam dokumen ILO, FAO, IFDAD, WHO Joint

Statement: Impact of COVID - 19 on People's Livelihoods, Their Health and Our Food System (WHO, 2020). Melalui dokumen tersebut, para organisasi internasional mengidentifikasi berbagai tantangan yang dihadapi oleh para pekerja agrikultur dalam masa pandemi. Tantangan yang dihadapi terjadi dalam berbagai level, baik dalam level individu sampai pada level sistem. Dalam level individu, para pekerja di bidang agrikultur, yang biasanya tidak mendapatkan jaminan sosial, akan menjadi semakin rentan ketika terinfeksi oleh virus corona, yang pada akhirnya akan 


\section{MANDALA:}

memberikan dampak terhadap produktivitas pekerja dan produksi pangan pada level nasional. Tidak berhenti sampai disini, COVID - 19 memberikan dampak yang signifikan terhadap sistem pangan akibat adanya kebijakan pembatasan yang diterapkan dalam masa pandemi, seperti penutupan perbatasan dan pembatasan perdagangan. Segala tantangan yang dihadapi oleh para pekerja di sektor agrikultur akan memberikan efek spillover terhadap ketahanan pangan, baik dalam level nasional dan global. Tantangan yang ada akan memberikan pengaruh terhadap produksi pangan di satu negeri, dan jika produksi tersebut terganggu, maka pada akhirnya ketahanan pangan akan terganggu. Selain aspek agrikultur, hal serupa juga terjadi dalam aspek lingkungan. Aspek lingkungan pada awal pandemi sempat menjadi perhatian para akademisi, hal tersebut disebabkan oleh peningkatan kualitas udara setelah penerapan kebijakan lockdown di beberapa negara. Kai Chen dari Yale School of Public Health menyatakan bahwa peningkatan kualitas udara merupakan peristiwa positif di tengah banyaknya kejadian buruk di berbagai negara (Chen, 2020). Serupa dengan pernyataan Chen, World Bank memberikan respon positif terhadap tingkat polusi yang mengalami penurunan karena belum ada kebijakan apapun di dunia yang berhasil meningkatkan kualitas udara yang membuat langit kembali terlihat bersih dan cerah (Narain, 2020). Walaupun demikian, isu lingkungan selama COVID - 19 menjadi semakin kompleks. Hal tersebut terjadi karena adanya peningkatan limbah medis secara signifikan sebagai akibat dari pertambahan aktivitas medis, baik dalam perawatan pasien yang terinfeksi maupun dalam bidang Research and Development mengenai uji coba kelayakan vaksin COVID - 19. Selain itu, adanya peningkatan pada jumlah penggunaan masker, sarung tangan dan alat pelindung diri juga menjadi faktor lain dalam peningkatan limbah medis. Menurut Asian Development Bank (2020), beberapa Ibu Kota di Asia Tenggara seperti Manila, Jakarta, Kuala Lumpur, Bangkok dan Ha Noi mengalami peningkatan limbah medis yang signifikan. Sehingga, pengelolaan limbah yang tepat mulai dari sektor rumah tangga, rumah sakit, dan lainnya, merupakan langkah krusial untuk meminimalkan dampak yang ada terhadap kesehatan dan berbagai aspek lainnya.

Tabel 1. Penambahan Limbah Medis

\begin{tabular}{|l|l|l|}
\hline \multicolumn{1}{|c|}{ Kota } & \multicolumn{1}{|c|}{ Populasi } & $\begin{array}{c}\text { Penambahan } \\
\text { Limbah Medis }\end{array}$ \\
\hline Manila & 14 juta & $280 \mathrm{t} / \mathrm{d}^{*}$ \\
\hline Jakarta & 10.6 juta & $212 \mathrm{t} / \mathrm{d}^{*}$ \\
\hline Bangkok & 10.5 juta & $210 \mathrm{t} / \mathrm{d}^{*}$ \\
\hline
\end{tabular}




\begin{tabular}{|l|l|l|}
\hline $\begin{array}{l}\text { Kuala } \\
\text { Lumpur }\end{array}$ & 7.7 juta & $154 \mathrm{t} / \mathrm{d}^{*}$ \\
\hline Ha Noi & 8 juta & $160 \mathrm{t} / \mathrm{d}^{*}$ \\
\hline
\end{tabular}

Source: Asian Development Bank (2020)

*Metric Ton $=1000$ kilogram, $t / d=$ metric tons/hari

Melalui penjelasan di atas, maka dapat disimpulkan bahwa COVID - 19 merupakan peristiwa unprecedented, yang terjadi pada isu Kesehatan Global. Dikutip melalui Towards a Common Definition of Global Health (Koplan, et al., 2009), Global Health atau Kesehatan Global merupakan terminologi yang mengacu pada kerjasama dalam penyakit yang memiliki beban tinggi, dimana negara berkembang belum tentu memiliki fasilitas kesehatan yang memadai (Koplan, et al., 2009). Hal tersebut yang pada akhirnya menjadi concern dari banyak aktor dalam hubungan internasional, yaitu fakta bahwa negara memiliki tingkat kapasitas dan kapabilitas yang berbeda dalam menangani COVID 19. Lebih lanjut, merujuk pada pernyataan Febrian A. Ruddyard selaku Direktur Jenderal Kerjasama Multilateral Kementerian Luar Negeri RI dalam Webinar FISIP UI 2020 Seri 6 : Pandemi Covid-19 dan Tantangan Kerjasama Multilateral, beberapa negara di awal pandemi menerapkan kebijakan Me First Policy, dimana masing - masing negara berusaha mengamankan kebutuhannya masing - masing, tanpa memperhatikan negara lainnya. Jika kebijakan Me First tersebut tetap dilaksanakan, maka penanganan pandemi tidak akan sepenuhnya efektif. Dalam situasi krisis, dimana setiap negara tidak memiliki kekebalan terhadap pandemi, seharusnya kerjasama merupakan langkah yang diambil. Jika dianalogikan, ketika hanya negara - negara maju yang berhasil menangani pandemi, negara tersebut tetap akan merasakan dampak dari pandemi, seperti dalam aspek pariwisata, perdagangan dan lainnya.

Merujuk pada pernyataan Kickbusch, Silberschmidt dan Buss (2007), Global Health Diplomacy merupakan proses negosiasi yang terjadi pada berbagai tingkatan (multi - level) yang membentuk dan mengelola pembentukan dari kebijakan global dalam isu kesehatan. Berdasarkan deskripsi yang telah dijelaskan, maka dapat disimpulkan bahwa Global Health Diplomacy merupakan instrumen yang paling relevan untuk diterapkan pada masa pandemi. Hal tersebut terjadi karena kerjasama yang dilakukan terjadi dalam berbagai tingkatan, untuk menyelesaikan segala permasalahan yang ada dan pada akhirnya akan membentuk kebijakan global dalam isu kesehatan. Selanjutnya, Global Health Diplomacy membuktikan bahwa isu kesehatan telah memasuki area kebijakan luar negeri dan mampu menembus 
kepentingan dari masing - masing negara. Paper ini berusaha untuk menganalisis Global Health Diplomacy yang diterapkan oleh Indonesia pada masa COVID - 19, untuk mengetahui apakah kebijakan tersebut bersifat kompetitif dan hanya mementingkan kepentingan negara sendiri atau bersifat kooperatif dengan memperhatikan aspek lain seperti kemanusiaan dan persamaan.

\section{Kerangka Pemikiran}

Global Health Diplomacy didefinisikan oleh Kickbusch, Silverschmidt dan Buss (2007) sebagai proses negosiasi yang terjadi pada berbagai tingkatan (multi level) yang membentuk dan mengelola pembentukan dari kebijakan global dalam isu kesehatan. Kebijakan global dalam isu kesehatan tidak hanya memiliki tujuan untuk mencapai health security bagi setiap negara yang terlibat di dalam proses negosiasi dan pembentukan kebijakan global dalam isu kesehatan, tetapi juga untuk meningkatkan relasi antar negara dan penguatan komitmen dari berbagai aktor dalam hubungan internasional untuk memastikan isu kesehatan sebagai bagian dari hak asasi manusia yang harus dipenuhi. Owen dan Roberts dalam (KhazatzadehMahani, 2019) menyatakan bahwa kemunculan isu - isu kesehatan menekankan pentingnya sebuah reformasi dalam tatanan negosiasi dalam
International Health Regulations (IHRs) serta pentingnya untuk mengembangkan kerjasama dalam tingkat global untuk mengontrol wabah penyakit. Global Health Diplomacy adalah proses negosiasi yang melibatkan beberapa aktor dan terjadi dalam berbagai tingkatan. Lebih lanjut, Kickbusch (2013) mendeskripsikan karakteristik dari Global Health Diplomacy, yaitu :

1) Sifat dari Isu Kesehatan. Global Health Diplomacy merupakan instrumen untuk membahas isu kesehatan. Namun, sebelum para aktor mengimplementasikannya, pemahaman terhadap sifat alamiah isu kesehatan diperlukan, dimana isu kesehatan bersifat lintas batas, sehingga kerjasama dibutuhkan untuk menyelesaikannya. Pemahaman dari setiap aktor mengenai sifat isu kesehatan dapat digunakan sebagai landasan untuk memperkuat komitmen masing - masing aktor dalam menyelesaikan masalah kesehatan.

2) Peran dari Ilmu Pengetahuan dan Ilmuwan. Mengacu pada pengertian Global Health Diplomacy, terdapat banyak aktor yang terlibat dalam pelaksanaan praktik diplomasi tersebut, khususnya adalah Ilmuwan. Hal tersebut terjadi karena setiap aktor dalam dunia internasional harus benar benar memahami key problems dari 
permasalahan yang ada. Peran ilmu pengetahuan dan ilmuwan sangat dibutuhkan untuk mengidentifikasi penyebab dari penyakit dan metode penyembuhan yang tepat dan efisien. Sehingga, kolaborasi antara diplomat dan ahli kesehatan sangat dibutuhkan dalam mengimplementasikan Global Health Diplomacy.

3) Kompleksitas Negosiasi. Kompleksitas dari Global Health Diplomacy terjadi karena adanya berbagai tingkatan, berbagai faktor dan berbagai aktor yang terlibat dalam praktik diplomasi tersebut.

4) Konsep Persamaan yang Unik. Global Health Diplomacy menekankan pentingnya penerapan dari aspek persamaan. Walaupun demikian, dalam implementasinya, konsep persamaan tersebut akan diterapkan berdasarkan kemampuan dan kapabilitas nasional sebuah negara. Hal tersebut dapat dilihat melalui perbedaan tingkatan harga untuk negara maju dan negara berkembang.

5) Penggunaan Pendekatan Inovatif. Dalam implementasinya, Global Health Diplomacy selalu menggunakan pendekatan yang inovatif. Hal tersebut merupakan sebuah konsekuensi yang harus diambil oleh aktor - aktor dalam hubungan internasional, sehingga resolusi yang dikeluarkan dapat menjawab tantangan yang diberikan oleh isu kesehatan.

Melalui karakteristik yang telah disampaikan di atas, maka dapat disimpulkan bahwa Global Health Diplomacy pada dasarnya membutuhkan kerjasama dari berbagai pihak dengan pendekatan inovatif untuk dapat menjawab tantangan yang diberikan oleh isu kesehatan. Walaupun demikian, Global Health Diplomacy tidak terlepas dari kepentingan suatu negara dalam hubungan internasional. Pendekatan isu kesehatan dalam diplomasi merupakan salah satu bentuk dan alat bagi negara untuk memiliki power dalam mempengaruhi dunia internasional dengan pendekatan yang lebih halus.

Dalam hubungan internasional, konsep tersebut dikenal dengan sebutan Soft Power. Soft Power merupakan sebuah konsep yang dipaparkan oleh Joseph S. Nye dalam 1990, dimana konsep tersebut menekankan pada kemampuan, yang dalam hal ini adalah negara, untuk menyakinkan orang lain untuk melakukan apa yang diinginkan oleh pihak pertama tanpa penggunaan kekerasan. Hal tersebut terjadi karena soft power dilakukan oleh negara mempengaruhi negara lain melalui penyebaran nilai, institusi dan budaya. Sehingga, ketika suatu negara berhasil 
menyebarkan nilai - nilai yang sesuai dengan tujuan bersama, negara tersebut akan dianggap berhasil dalam mengimplementasikan soft power.

Selanjutnya, keberadaan konsep soft power dalam praktik Global Health Diplomacy terletak dalam instrumen yang digunakan dalam diplomasi tersebut, yaitu recommendations / resolutions (yang dianggap sebagai instrumen 'soft', hal tersebut terjadi karena rekomendasi dan resolusi yang diberikan tidak mengikat negara anggota); international agreements and conventions (berbeda dengan rekomendasi dan resolusi, perjanjian internasional bersifat lebih mengikat dan dianggap sebagai 'hard law'); regulations (regulasi bersifat lebih mengikat dan dianggap sebagai 'hard obligations').

Proses negosiasi dari Global Health Diplomacy lebih menekankan persamaan nilai dan tujuan, walau pada akhirnya interpretasi dan implementasi dari masing masing negara akan berbeda antara satu dengan yang lainnya. Melalui persamaan nilai, para pemangku kepentingan akan mengakomodasikan kepentingan dari masing - masing pihak, sehingga solusi baru dapat terbentuk.

\section{Peran Indonesia dalam Global Health}

Diplomacy COVID - 19

Dalam situasi pandemi, Indonesia harus menyesuaikan diri dengan setiap perubahan yang ada. Salah satu bentuk adaptasi yang dilakukan oleh Indonesia dalam masa Pandemi adalah memfokuskan kembali prioritas diplomatik dari Indonesia. Hal tersebut sesuai dengan pernyataan Menlu Retno Marsudi dalam Pernyataan Pers Tahunan Menlu (PPTM) 2021. Dalam PPTM, Retno Marsudi menyampaikan capaian diplomasi yang dilakukan oleh Indonesia pada 2020, salah satunya adalah memfokuskan kembali prioritas diplomatik Indonesia, sesuai dengan keadaan pandemi. Prioritas tersebut adalah menguatkan perlindungan terhadap Warga Negara Indonesia (WNI), mendukung respon nasional dalam menghadapi dampak kesehatan dan dampak sosio-ekonomi akibat COVID - 19, dan untuk melanjutkan kontribusi Indonesia dalam perdamaian dan keamanan dunia.

Melalui prioritas diplomatic yang kembali difokuskan, Indonesia menggunakan instrumen Global Health Diplomacy dalam mewujudkan prioritas tersebut, secara khusus prioritas kedua. Global Health Diplomacy bukan hal yang baru bagi Indonesia, hal tersebut terjadi karena Indonesia merupakan negara yang pada beberapa tahun terakhir mulai menunjukkan ketertarikan pada diplomasi kesehatan. Dalam kajian mandiri "Kesehatan untuk Semua: Strategi Diplomasi Kesehatan Global Indonesia“, 
Maryadi, et al (2018) memaparkan bahwa kontribusi Indonesia dapat dianalisis dengan konsep International Collective Action, yaitu:

1. Kepemimpinan. Dalam hal ini, aktor internasional akan dikatakan berhasil dalam menunjukkan kepemimpinannya jika mereka memiliki peran dan terlibat secara aktif dalam perumusan suatu resolusi sebagai hasil dari proses negosiasi dan perundingan internasional. Lebih lanjut, pendekatan ini menekankan pada aspek konsensus pada proses perumusan resolusi, hal tersebut terjadi agar para aktor menemukan core values dari suatu permasalahan. Kepemimpinan Indonesia dalam Global Health Diplomacy dapat dilihat melalui peran Indonesia dalam mencetuskan resolusi Global Solidarity to Fight COVID - 19. Resolusi yang disetujui pada 2 April 2020 tersebut merupakan resolusi PBB yang pertama dalam membahas COVID - 19. Dikutip dari website Kemlu, Menteri Luar Negeri Retno Marsudi menyatakan bahwa kerjasama yang dilakukan antara Indonesia Singapura, Ghana, Liechtenstein, Norwegia dan Swiss, bertujuan untuk menyampaikan dan mempromosikan pendekatan solidaritas dan kolektif dalam menyelesaikan dan menangani pandemi COVID - 19. Lebih lanjut, dalam bagian preambulatory, keenam negara menekankan pentingnya rasa solidaritas, yang diimplementasikan melalui kolaborasi dalam tingkat nasional, regional maupun global dengan stakeholder yang relevan untuk memastikan tercapainya tujuan pembangunan berkelanjutan, yaitu no one left behind. Selanjutnya, resolusi tersebut juga menekankan pentingnya untuk merespon dampak sosial dan ekonomi untuk mengatasi COVID 19 dengan pendekatan yang inklusif serta berkelanjutan.

\section{Memastikan Tersedianya Public}

Goods. Dalam kategori ini, pendekatan inovatif dan penemuan instrumen baru dalam isu kesehatan dibutuhkan oleh aktor internasional. Pendekatan yang inovatif dibutuhkan untuk dapat menjawab tantangan yang diberikan oleh isu kesehatan, yang memberikan dampak hampir ke seluruh aspek kehidupan. Bentuk implementasi yang dilakukan oleh tiap - tiap aktor 
hubungan internasional dalam memastikan tersedianya public goods dapat terjadi dalam berbagai bentuk, seperti Generation and Sharing Knowledge dan Sharing of Intellectual Property (Maryadi, et al., 2018). Dalam pandemi COVID - 19, seperti yang telah dijelaskan dalam resolusi A/RES/74/270, berbagai aktor dalam hubungan internasional disarankan untuk menggunakan pendekatan yang berbasis solidaritas. Hal tersebut diimplementasikan dalam program Solidarity Trial yang dilaksanakan oleh WHO dalam upaya untuk memastikan inklusivitas vaksin dan treatment untuk COVID - 19. Program ini berusaha untuk melakukan evaluasi terhadap dampak dari obat terhadap pasien COVID - 19 dengan menekankan pada kematian, kebutuhan dalam penggunaan ventilasi dan durasi perawatan di rumah sakit. Indonesia merupakan salah satu dari 45 negara yang berpartisipasi dalam riset tersebut. Dalam program tersebut, terdapat 22 rumah sakit yang terlibat dalam riset uji klinis, diantaranya adalah RSUP Persahabatan, RSUP Dr. Soetomo (Litbangkes, 2020). Selain itu,
Indonesia merupakan salah satu negara yang kerap menyerukan agar Vaksin tercipta sebagai public goods, baik dalam tingkat multilateral maupun tingkat bilateral. Dalam tingkat multilateral, Indonesia dalam G20 melalui perwakilannya, yaitu Rizal Affandi Lukman selaku Deputi Bidang Koordinasi Kerjasama Ekonomi Internasional, mendorong upaya pengembangan vaksin yang berkualitas, aman dan efektif dan menekankan pentingnya upaya untuk mengembangkan vaksin yang dapat diakses secara universal.

\section{Pendampingan Negara secara}

Langsung. Selain kerjasama pada tingkat mulilateral, kerjasama pada tingkat bilateral, juga dibutuhkan untuk saling mendukung dan melengkapi satu dengan lainnya. Dalam hal ini, kerjasama bilateral dapat dilihat melalui kesepakatan antara BUMN Indonesia, yaitu Bio Farma dan Sinovac asal China. Menteri Luar Negeri Retno LP Marsudi telah mengumumkan kesepakatan itu pada konferensi pers virtual di Sanya, China selatan. Dalam kerjasama tersebut, Bio Farma menandatangani dua kesepakatan tentang kerjasama 
vaksin dengan Sinovac. Berdasarkan kesepakatan pertama, Sinovac akan mulai mengirimkan vaksin virus corona ke Indonesia pada November. Kesepakatan kedua adalah MoU antara kedua belah pihak untuk memperpanjang kerjasama hingga akhir 2021, di mana Sinovac berkomitmen untuk memberikan akses prioritas kepada Bio Farma untuk membeli lebih banyak vaksin curah. Sinovac pekan lalu meluncurkan tahap akhir uji klinis fase tiga untuk vaksin CoronaVac yang dikembangkan bersama Bio Farma, dengan tahap akhir melibatkan 1.620 relawan pasien di Bandung, Jawa Barat (Septiari, 2020). Selain itu, dikutip dari Website Kementerian Luar Negeri, bahwa pada 12 Oktober 2020, Menlu Retno dan Menteri BUMN Erick Thohir telah mengunjungi London, Inggris dan Jenewa, Swiss untuk melakukan pengamanan terhadap komitmen dari sumber lain mengenai Vaksin COVID - 19 dalam rangka kerjasama vaksin bilateral dan untuk menguatkan kerjasama dalam jangka menengah dan jangka panjang antara Bio Farma dengan mitra di luar negeri.

\section{Analisis Global Health Diplomacy}

\section{Indonesia: Kooperatif atau Kompetitif?}

Indonesia merupakan salah satu negara yang sejak awal bertindak dengan konsisten dalam penanganan pandemi. Indonesia, sebagai middle power, selalu berusaha untuk mempromosikan nilai nilai kolektivitas dan solidaritas dalam mengatasi pandemi. Hal tersebut dilatarbelakangi akibat adanya tantangan baru dalam kerjasama multilateral, dimana seperti yang telah dijelaskan oleh Febrian A. Ruddyard selaku Direktur Jenderal Kerjasama Multilateral Kementerian Luar Negeri RI, altruisme global mengalami pergeseran dengan kemunculan me first policy. Maka dari itu, Indonesia mengambil langkah yang cepat dan tepat melalui publikasi resolusi PBB, yaitu Global Solidarity to Fight COVID - 19. Jika ditinjau dari karakteristik Global Health Diplomacy yang disampaikan oleh Kickbusch (2013), bahwa setiap aktor dalam hubungan internasional harus dapat memahami bahwa isu kesehatan merupakan permasalahan lintas batas, sehingga kerjasama merupakan instrumen yang tepat untuk diimplementasikan dalam situasi krisis ini. Melalui penjelasan di atas, dapat disimpulkan bahwa Indonesia melalui Kementerian Luar Negeri menyadari bahwa COVID - 19 tidak hanya memberikan dampak dalam aspek 
kesehatan hanya kepada satu negara, melainkan COVID - 19 merupakan permasalahan lintas sektor akibat adanya dampak spillover dan permasalahan lintas batas yang terjadi di seluruh dunia, dimana tidak ada negara yang memiliki kekebalan terhadap pandemic COVID - 19. Hal tersebut sesuai dengan dokumen Global Solidarity to Fight COVID - 19, dimana pada bagian preambulatory, setiap negara sertuju untuk melakukan kolaborasi dalam berbagai level, seperti nasional, internasional dan global dengan berbagai stakeholder baik aktor negara maupun aktor non negara, untuk memastikan tercapainya tujuan pembangunan berkelanjutan. Selanjutnya, resolusi tersebut juga menekankan pentingnya untuk merespon dampak sosial dan ekonomi untuk mengatasi COVID - 19 dengan pendekatan yang inklusif serta berkelanjutan.

Selanjutnya, melihat permasalahan COVID - 19 yang sangat kompleks, Indonesia menggunakan berbagai pendekatan inovatif, khususnya dalam kerjasama di bidang vaksin, baik dalam tingkat multilateral maupun bilateral. Seperti yang telah tertuang dalam resolusi Global Solidarity to Fight COVID - 19, negara disarankan untuk menggunakan pendekatan yang berbasis solidaritas. Indonesia merupakan salah satu negara yang sejak awal pandemik selalu konsisten untuk

$$
\text { menggunakan }
$$

pendekatan

solidaritas. Pada tingkat multilateral, Indonesia berperan aktif di berbagai forum multilateral, seperti misalnya dalam WHO melalui program Solidarity Trial dalam upaya untuk memastikan inklusivitas vaksin dan treatment untuk COVID - 19. Melalui program yang bertujuan untuk melakukan evaluasi terhadap dampak dari obat terhadap pasien COVID - 19 dengan menekankan pada kematian, kebutuhan dalam penggunaan ventilasi dan durasi perawatan di rumah sakit ini, pendekatan solidaritas yang tertuang dalam resolusi Global Solidarity to Fight COVID - 19 dilaksanakan dengan baik oleh Indonesia. Selain itu, pernyataan yang disampaikan oleh Indonesia dalam G20 mengenai pengembangan vaksin yang berkualitas, aman dan efektif, yang dapat diakses secara universal, merupakan contoh lain dari kerjasama di tingkat multilateral yang diupayakan oleh Indonesia.

Selain itu, pada tingkat bilateral, Indonesia melakukan kerjasama dengan beberapa negara mengenai vaksin COVID - 19. Kerjasama pada level bilateral dimaksudkan untuk melengkapi usaha yang telah dilakukan oleh Indonesia pada level multilateral melalui penekanan terhadap aspek solidaritas. Hal tersebut sesuai dengan konsep Global Health Diplomacy yang didefinisikan oleh Kickbusch, 
Silverschmidt dan Buss (2007) bahwa proses negosiasi tersebut harus terjadi dalam berbagai tingkatan, yang pada akhirnya akan membentuk dan mengelola pembentukan dari kebijakan global dalam isu kesehatan. Sesuai dengan sifat alamiah dari isu kesehatan yang bersifat kompleks, maka kerjasama harus dilakukan dalam berbagai tingkatan, untuk saling melengkapi kerjasama yang ada. Kerjasama bilateral tersebut terjadi dengan China, Inggris dan Swiss untuk melakukan pengamanan komitmen dari sumber lain mengenai Vaksin COVID - 19 dalam rangka kerjasama vaksin bilateral dan untuk menguatkan kerjasama dalam jangka menengah dan jangka panjang antara Bio Farma dengan mitra di luar negeri.

Melalui penjelasan di atas, dapat disimpulkan bahwa arah dari Global Health Diplomacy yang dilakukan oleh Indonesia pada COVID - 19 bersifat kooperatif. Hal tersebut sesuai dengan setiap peran yang dilakukan oleh Indonesia, baik dalam level multilateral sampai ke level bilateral. Dalam setiap kerjasama yang dilakukan, hal yang menjadi concern utama dari Indonesia adalah untuk menekankan aspek solidaritas, sehingga setiap negara tidak hanya memikirkan kepentingannya saja, sehingga Indonesia berusaha untuk mengembalikan altruisme global yang mendapatkan tantangan dalam pandemi.
Selain aspek solidaritas, Indonesia juga menekankan aspek persamaan, khususnya dalam pendistribusian vaksin. Walaupun konsep persamaan yang digunakan dalam Global Health Diplomacy merupakan pendekatan yang unik, karena pendistribusian tersebut akan didasari oleh tingkat vulnerabilities suatu negara, namun langkah yang diambil oleh Indonesia merupakan langkah yang tepat, sehingga semua negara memiliki kesempatan untuk mendapatkan akses terhadap vaksin, dengan harga yang terjangkau.

Fathun dan Situmeang mengatakan bahwa global helath diplomacyadalah metode kerjasama internasional merupakan model kerjasama yang komprehensif dalam hubungan internasional. Dengan metode ini negara-negara akana berfikir kompleks untuk memikirkan negara lain. Karena poin dari kerjasama dalam bidang Kesehatan adalah penyakit yang menyebar. Sehingga kerjasama kesehetahan adalah kerjasama global dana saling bersinergi. Untuk itu, kerjasama Kesehatan mempertimbangkan keamanan, hak asasi manusia, perdagangan global dan Kesehatan public. Metode diplomasi Kesehatan harus bersifat saling mengayomi karena sifatnya isu Kesehatan lebih tinggi dari pada isu politik dan ekonomi, bersifat altruism dan saling bersinergi. (L.M.Fathun \& Nurmasari S, 2021) 
Global Health Diplomacy yang dilakukan oleh Indonesia tidak hanya memberikan dampak yang signifikan terhadap negara - negara berkembang lainnya, namun juga memberikan pengaruh yang besar kepada Indonesia. Menurut Lowy Institute (2018), Indonesia merupakan negara middle - power dengan menempati posisi 10 pada keseluruhan variabel, dan posisi 9 pada kekuatan pengaruh diplomasi. Sehingga, untuk mewujudkan wibawa diplomasi, Indonesia berusaha untuk meningkatkatkan legitimasinya dalam hubungan internasional melalui soft power. Selain itu, indikator yang harus dilakukan Indonesia untuk meningkatkan pengaruhnya adalah dengan memperluas hubungan diplomasi, meningkatkan kerjasama multilateral dan menunjukkan kepemimpinannya dalam berbagai isu. Konsep soft power dalam praktik Global Health Diplomacy Indonesia terletak dalam penggunaan instrumen yang digunakan dalam diplomasi tersebut, yaitu recommendations / resolutions. Dalam resolusi A/RES/74/270, peraturan yang ada di dalamnya tidak mengikat dan norma norma yang ada di dalamnya merupakan susunan dari norma - norma yang dasar tanpa ada mekanisme lebih lanjut mengenai implementasi dari solusi yang ada. Namun, rekomendasi dan resolusi tetap memiliki dampak yang signifikan dalam hubungan internasional. Hal tersebut memiliki manfaat untuk mengatur serta menyelaraskan posisi dari setiap negara dalam mengatasi isu COVID - 19. Seperti yang sudah dijelaskan sebelumnya, proses negosiasi dari Global Health Diplomacy lebih menekankan persamaan nilai dan tujuan, walau pada akhirnya interpretasi dan implementasi dari masing - masing negara akan berbeda antara satu dengan yang lainnya.

\section{Kesimpulan}

Dengan adanya pandemi COVID 19, Indonesia menyadari bahwa dampak yang terjadi tidak hanya dalam aspek kesehatan melainkan dapat mempengaruhi aspek-aspek lain, dimana setiap negara merasakan dampak yang sama dan tidak dapat terhindar dari pandemi COVID - 19. Dalam menghadapi pandemic COVID - 19, setiap negara setuju untuk melakukan kolaborasi dalam berbagai level, seperti nasional, internasional, dan global dengan berbagai stakeholder dari aktor negara maupun non negara untuk memastikan tercapainya tujuan pembangunan berkelanjutan, hal ini sesuai dengan dokumen Global Solidarity to Fight COVID - 19 yang telah disetujui oleh setiap negara.

Munculnya permasalah COVID 19 yang lebih kompleks membuat Indonesia lebih menggunakan pendekatan 


\section{MANDALA:}

yang inovatif yang mengedepankan kerjasama dalam tingkat multilateral dan bilateral serta menekankan sikap solidaritas kepada negara lain tanpa melihat vulnerabilities suatu negara, sehingga setiap negara memiliki kesempatan yang sama dalam mendapatkan vaksin.

\section{Referensi}

Bank, A. D. (2020, April). Managing Infectious Medical Waste during the COVID-19 Pandemic.

Retrieved from Asian Development Bank:

https://www.adb.org/publications/ managing-medical-waste-covid19

Chen, K. (2020, May 14). In China, strict quarantine improves air quality and prevents thousands of premature deaths. Retrieved from YALE School of Medicine: https://medicine.yale.edu/newsarticle/24721/

Khazatzadeh-Mahani, A. R. (2019). Global Health Diplomacy. The Oxford Handbook of Global Health Politics, 103.

Kickbusch, I., Silberschmidt, G., \& Buss, P. (2007). Global Health Diplomacy: The Need for New Perspectives, Strategic Approaches and Skills in Global Health. Bulletin of the World Health Organization, 85 (3), 230 - 232.

Kickbusch, I. (2013). 21st Century Health Diplomacy: A New Relationship between Foreign Policy and Health. In I. Kickbusch, \& M.
Told, 21st Century Global Healty Diplomacy (pp. 1 - 40).

Koplan, J., Bond, T., Merson, M., Reddy, K., Rodriguez, M., Sewankambo, N., \& Wasserheit, J. (2009). Towards a Common Definition of Global Health. Viewpoint, 1993 1995.

Litbangkes. (2020, April 24). Badan Litbangkes Kementerian Kesehatan $R I$. Retrieved from Solidarity Trial, Simbol Semangat Kebersamaan dan Kesatuan dalam Melawan Covid- 19: https://www.litbang.kemkes.go.id/s olidarity-trial-simbol-semangatkebersamaan-dan-kesatuan-dalammelawan-covid-19/

L.M. Fathun \& Nurmasari S. (2021).

Oncept Of Global Health

Diplomacy In International

Relations. AEGIS : Journal of International Relations.

Lowy Institute. (2018). Asia Power Index. Lowy Institute.

Maryadi, H. L., Dewi, E. D., Aryadi, T., Santikajaya, A., Fitri, W., \& Putro, R. A. (2018). Kementrian Luar Negeri . Retrieved from https://kemlu.go.id/download/L3N pdGVzL3B1c2F0L0RvY3VtZW50 cy9LYWppYW41MjBCUFBLL1A zSyUyME9JLU1VTFRJTEFURVJ BTC8wN19LZXNlaGF0YW5fdW5 0dWtfU2VtdWEucGRm

Narain, U. (2020, July 2). Air Pollution: Locked Down by COVID - 19 but Not Arrested. Retrieved from The World Bank: 
https://www.worldbank.org/en/new s/immersive-story/2020/07/01/airpollution-locked-down-by-covid19-but-not-arrested

Negeri, K. L. (2020, April 3). Kementerian Luar Negeri Indonesia. Retrieved from Indonesia Sukses Loloskan Resolusi PBB Perdana Tentang Solidaritas Global Atasi COVID19:

https://kemlu.go.id/portal/en/read/1 160/view/indonesia-successfullypasses-the-first-un-resolution-onglobal-solidarity-to-overcomecovid-19

Septiari, D. (2020, August 21). The Jakarta Post. Retrieved from
Government, Bio Farma secure vaccine bulk supply from China's Sinovac:

https://www.thejakartapost.com/ne ws/2020/08/21/retno-bio-farmasecure-vaccine-bulk-supply-fromchinas-sinovac.html

WHO. (2020, October 13). Impact of COVID-19 on people's livelihoods, their health and our food systems. Retrieved from World Health Organization: https://www.who.int/news/item/1310-2020-impact-of-covid-19-onpeople's-livelihoods-their-healthand-our-food-systems 